\section{The face of justice?}

John C. Marshall

Identifying Ivan: A Case Study in Legal Psychology. By Willem A. Wagenaar. Harvester-WheatsheaflHarvard University Press: 1988/1989. Pp. 187. £13.95, \$20.

All trials are, or should be, 'show trials'. In accordance with the axiom "Justice must not only be done, but must be seen to be done", they should show as unambiguously as possible whether the accused is innocent or guilty as charged. Nazi and Stalinist show trials were obnoxious not because they were spectacles, but because those found guilty were so manifestly innocent.

Last April, a Jerusalem court sentenced John Demjanjuk to death after a trial explicitly stage-managed to remind Israel's youth of the Jewish past in Europe; his appeal is pending. The crime is not at issue. A Ukrainian guard at Treblinka death camp was, in part, responsible for the murder of 850,000 Jews in the gas chambers. The court decided that this man, known to the prisoners as Ivan the Terrible, was John Demjanjuk, a factory worker from Cleveland, Ohio, who had been extradited from the United States to stand trial in Israel. Demjanjuk's defence was simple in principle, although just how complex in fact is revealed by Willem Wagenaar's monograph Identifying Ivan: $A$ Case Study in Legal Psychology. The defence was mistaken identity - that Demjanjuk was not 'Ivan'.

Willem Wagenaar is a distinguished Dutch scientist who holds the chair of Experimental Psychology at the University of Leiden. His areas of professional competence include the study of memory and perception. $\mathrm{He}$ is an acknowledged expert on identification procedures and eyewitness testimony, and it is in this capacity that he agreed to act in the defence of John Demjanjuk. Other equally qualified psychologists had declined to so testify, fearful apparently of the reactions of friends and colleagues. Wagenaar's decision (and the whole tone of his book) is evidence of his intellectual and moral strength; both his character and the technical nature of his testimony have subsequently been vilified and distorted by many who ought to know better.

Quite apart from the specific discussion of Demjanjuk's case, the book is a vivid tutorial on the reliability (or otherwise) of facial identification and the rules for the conduct and interpretation of identity tests. These are areas to which experimental psychologists have made substantial contributions and have succeeded in

elucidating a wide range of perceptual, memorial, cognitive and social factors that affect the validity of identification judgements; studies of this topic deliver highly pertinent information to counter those who argue that empirical psychology is conceptually vacuous and socially useless.

Wagenaar summarizes the relevant experimental evidence superbly and provides an acute analysis of its strengths and weaknesses; he falls into neither the trap of assuming that the expert is always right, nor that of dismissing scientific work because the knowledge so obtained is itself limited and fallible. Furthermore, he convincingly relates such laboratory studies to well-documented cases where flaws in line-up and show-up procedures are known (in retrospect) to have resulted in a miscarriage of justice. A number of Wagenaar's conclusions were prefigured in the document prepared by a British advisory committee, chaired by Lord Devlin (1976). Wagenaar pays due tribute to the Devlin Report, although the pace of research has now materially added to the body of information available. His monograph should accordingly be obligatory reading for all judges and lawyers - or better, for all citizens.

The central section of Identifying Ivan is a description and justification of 50 procedural rules for the fair conduct of identity parades. They include such seemingly reasonable requirements as (Rule 17): "Witnesses should, before participation in an identification test, be requested to

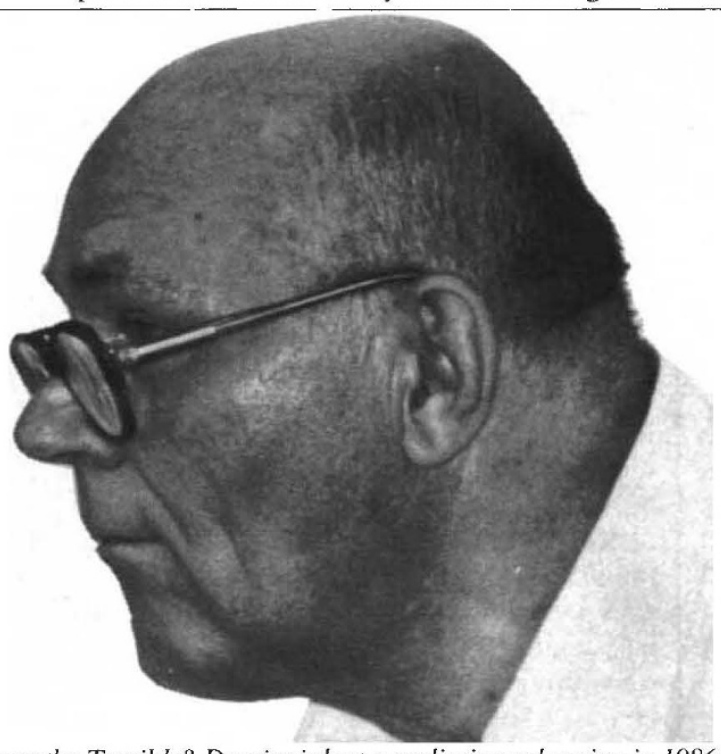

an the Terrible? Demjanjuk at a preliminary hearing in 1986

provide a verbal description of the criminal, as they remember him. These descriptions should be included in the reports of the subsequent identity test". And (Rule 21): "The instruction to the witnesses should stress that the wanted person is possibly not in the parade or photospread, and that therefore a positive response should be made only when the witness is certain of recognizing that person".

It is Wagenaar's contention that of the 46 rules applicable to Demjanjuk's case, 28 were directly broken and another nine violated by implication from earlier flaws. Similar procedural errors were made, Wagenaar claims, at the Cleveland trial in 1981 when Demjanjuk's US citizenship was revoked. It is true, as Wagenaar readily concedes, that not all of these rules are accepted as an international standard. Nonetheless, the least that can be said on the basis of his quietly rational documentation is that justice was not seen to be done. Such violations could not, of course, occur in Britain. But at a time when the British government is attempting (with some success) to turn the state into an appendage of MI5, we should perhaps be aware of the problem.

Professor Wagenaar does not pretend to the wisdom of Solomon, and he is far too intelligent a man to dispute the verdict of the Jerusalem court. That decision was based upon more evidence than is available to an expert witness for the defence. As Wagenaar states: "The process of translating prior odds into posterior odds is influenced by the experts' likelihoods, but not determined by them". For the reader who wants to know the Truth, Wagenaar "can only refer to the court's verdict". It is, he writes, "the best answer we have".

I do, however, take away from his book one firm conclusion. We can all agree that no legal process will be perfect (at least until the Messiah comes); but there is, to my mind, a strong case to be made that all expert testimony should be presented not by 'experts' for the prosecution or the defence, but rather by 'friends of the court'. Until that day, Wagenaar might like to recall an old Yiddish story: The rabbi's wife was convinced that her servant girl was stealing from her. She told the rabbi that she intended to take the girl to court. When the rabbi said that he too would go, the rebbetzin informed him that she knew the law as well as he did and could successfully prosecute on her own. "Ah, yes", said the rabbi, "but who save me will dare to testify in your servant's defence?".

John C. Marshall is in the Neuropsychology Unit, part of the Neuroscience Group at the Radcliffe Infirmary, Oxford $0 X 26 \mathrm{HE}, \mathrm{UK}$. 